\title{
Journal of Contemporary Accounting
}

\section{Factors that affect audit quality}

\author{
Ramadhani Calocha \\ Accounting Department, Universitas Jenderal Soedirman, Purwokerto, Indonesia \\ Eliada Herwiyanti \\ Accounting Department, Universitas Jenderal Soedirman, Purwokerto, Indonesia \\ elly_idc@yahoo.com
}

Follow this and additional works at: https://journal.uii.ac.id/jca

Copyright (C2020 Journal of Contemporary Accounting and Authors.

Ramadhani Calocha \& Eliada Herwiyanti. (2020). Factors that affect audit quality. Journal of Contemporary Accounting, 2(1), 35-48. doi:10.20885/jca.vol2.iss1.art4 


\title{
Factors that affect audit quality
}

\author{
Ramadhani Calocha ${ }^{1}$, Eliada Herwiyanti ${ }^{2 *}$ \\ 1,2 Accounting Department, Universitas Jenderal Soedirman, Purwokerto, Indonesia
}

\begin{abstract}
JEL Classification:
M42, M41

Keywords:

Audit experience, auditor professionalism, time budget pressure, audit tenure, knowledge of detecting errors, audit quality.
\end{abstract}

${ }^{*}$ Corresponding Author:

elly_idc@yahoo.com

DOI:

10.20885/jca.vol2.iss1.art4

Copyright (C2020

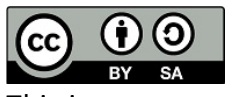

This is an open access under CC-BY-SA LICENSE

\begin{abstract}
The title of this research is factors that affect audit quality. This research aims to know, analyze, and show the effects of the relationship between experience, auditor professionalism, time budget pressure, audit tenure, and knowledge of detecting errors on audit quality. The research population is all auditors at a public accounting firm in Jakarta. This research used a purposive sampling technique with some criteria for the research sample. The research sample obtained was 89 respondents. This research used survey technique as collecting the data with sharing questionnaire and multiple linear regression with SPSS software for the data analysis technique. The result of this study indicates that auditor experience and knowledge of detecting errors have a positive effect and significant on audit quality, whereas auditor professionalism, time budget pressure have a positive effect but not significant on audit quality and audit tenure have a negative effect but not significant on audit quality to the auditors at a public accounting firm in Jakarta. This result of the research is expected to be means of self-introspection for a public accounting firm in Jakarta or other regions to increasing audit quality through attention to the auditor's experience and knowledge of detecting errors.
\end{abstract}

\section{Introduction}

The development of the business world today has explained that the need for an audit process is increasing. This is because the ownership of a business entity consisting of shares and investments can be owned by various parties. The separation between shareholders and company managers (management) requires that financial reports prepared and presented by management to shareholders are checked for accuracy and fairness by applicable regulations.

A Statement of Basic Auditing Concepts (ASOBAC), defines auditing as a systematic process undertaken to objectively collect and evaluate evidence regarding the assertion of various economic actions or events to determine the level of conformity between these assertions. Audit activities are conducted by third parties or outside parties that are independent, and this is very important for a company to do (Probohudono et al., 2019). The performance of the audit process will be illustrated in an audit report that becomes the benchmark for audit quality. Independent party audit reports are used by three interest groups, namely managers of the company being audited, company shareholders, and third parties or external parties such as potential investors, creditors, and suppliers. It can be said that the audit is an inspection process carried out by an independent party to reduce the probability of misalignment of information contained in the manager and the holders of the financial statements. Users of financial statements, especially shareholders, will make decisions based on an independent party audit report regarding the fairness of the presentation of a company's financial statements. This explains that the independent party has an important role in ratifying a company's financial statements.

The public accounting profession is a profession of public trust. Public accounting is a profession of the public trust because public accountants have a major responsibility to provide the correct assessment for the presentation of the company's financial statements. Through the 
work of public accountants, reliable information can be obtained as a basis for decision making (Arisinta, 2013). The public accounting profession is responsible for increasing the reliability of the company's financial statements so that the public can obtain reliable financial report information as a basis for decision making, especially shareholders. The great trust of users of audited financial reports and other services provided to public accountants is a big responsibility that requires public accountants to pay attention to the quality of the audits they produce. Behn et al. (2008) state that high audit quality, can increase the reliability of financial statement information and this is useful for helping shareholders (investors) in determining the firm's estimated value more precisely.

The factors of work experience and professionalism are requirements for external auditors by applicable auditing standards to strengthen audit quality accompanied by learning about seeing and adapting to changes in the audit scope. Moroney and Carey (2011) state that adequate work experience can improve one's performance in completing tasks. The longer the work experience an external auditor has, the better the audit quality will be. Then, professionalism influences audit quality and auditor quality which affects the auditor's performance as an employee (Wardayati et al., 2019).

Apart from the experience and professionalism of the external auditors, the quality of the external auditors' performance is also influenced by time budget pressure and audit tenure. The findings show that time budget pressure lowers the quality of audits performed by Swedish auditors (Broberg et al., 2017). Nasser et al. (2006) stated that the loss of auditor independence caused by the involvement of personal relationships with clients can affect their mental attitudes and opinions. Davis et al. (2002) stated that the longer the audit engagement period (tenure) between the auditor and the client company, the lower the quality of the audit report on the financial statements.

Various phenomena take the form of irregularities or violations around audit quality, namely the case of Enron Corporation at the end of 2001 with the Public Accounting Firm Arthur Andersen as its public accountant service. Enron's bankruptcy was seen as the result of poor audit quality. It is proven that Public Accountant Arthur Andersen was found guilty of being involved in collaborating with company management in manipulating Enron Corporation's financial data. The motive for this incident was a problem of the independence of the Arthur Andersen Public Accounting Firm, which was also poor because it had an audit engagement period (tenure) that lasted 20 years with its client, namely Enron Corporation.

The next phenomenon is based on WE Online (2017), namely the presence of two auditors of the Public Accounting Firm Klynveld-Peat-Marwick-Goerdeler (KPMG) and PricewaterhouseCoopers (PWC) who were subject to sanctions in the form of fines of millions of pounds for failing in their audits resulting in poor audit quality. KPMG was declared to have failed an audit by the Securities and Exchanges Commission (SEC) of energy company Miller Energy Resources by being proven to help provide an unqualified opinion on the financial statements of the company's actions in manipulating the increase in the carrying value of its assets significantly by 100 times its real value in the 2011 financial statements. Meanwhile, $\mathrm{PwC}$ was fined and criticized by the Financial Reporting Council after PwC admitted an error in its audit of RSM Tenon Group in the 2011 financial year.

Research on auditor experience conducted by Mulyadi (2013) shows that auditor experience has a significant and positive effect on audit quality. The results of research on the experience of auditors by Slamet (2012), Nirmala et al. (2013), Wulandari et al. (2014)is similar to Mulyadi's (2013) research which states that auditor experience has a significant and positive effect on audit quality. This result is different from the research of Futri and Juliarsa (2014) which contradicts previous research because it shows that auditor experience has no effect on audit quality. Research on auditor professionalism by Mulyadi (2013) states that auditor professionalism has a significant positive effect on audit quality. Meanwhile, according to research by Futri and Juliarsa (2014), auditor professionalism has no effect on audit quality. Time budget pressure research conducted by research by Ningsih and Yaniartha (2013) shows time budget pressure has 
a significant negative effect on audit quality. Nirmala et al. (2013) research also supports the results of previous studies, namely that time budget pressure has a significant negative effect on audit quality. Meanwhile, research by Zam and Rahayu (2015) contradicts previous research which states that time budget pressure has no significant positive effect on audit quality, Arisinta (2013) further states that time budget pressure affects audit quality.

Research on audit tenure has been conducted by Kurniasih and Rohman (2014) which states that audit tenure has a significant negative effect on audit quality. This research is also supported by Panjaitan and Chariri (2014), while research by Wulandari et al. (2014) contradicts previous research which states that audit tenure has no significant and positive effect on audit quality. Research on the knowledge of detecting errors was conducted by Hilman et al. (2015) which states that knowledge of detecting audits affects audit quality.

Based on this description, the selection of this research topic is due to the existence of phenomena and differences in previous research in the background described. This study refers to the research of Ningsih and Yaniartha (2013) by adding 4 variables, namely experience, auditor professionalism, audit tenure, and knowledge of detecting errors which will be analyzed for their impact on the quality of audits conducted by auditors at the Public Accounting Firm but do not use competency and independence variables. The research was conducted in the city of Jakarta because the city of Jakarta is a large city that is the business center of the capital which is associated with a public accounting firm. Several other things that support KAP in Jakarta being sampled are the varying size of KAP, of course, some auditors have experience, professionalism, audit quality in their duties, have public trust, and have tenure with the auditee.

\section{Literature Review}

\section{Agency Theory}

Jensen and Meckling (1976)state that agency theory is a theory that explains the existence of an agreed relationship between one or more parties who own the company (principal), in this case, including shareholders who employ company management (agents). The agent is expected to perform some services on behalf of the principal. In a company, an agency relationship is a relationship between shareholders (principals) and company management (agents) or called managers. The agent is the authorized party to manage and make decisions regarding the company on behalf of the shareholders. Differences in interests between principals and agents will create agency conflicts within the company due to information asymmetry. Agents know more about the company's internal information and prospects than the principal. Therefore, it is necessary to disclose information through an audit program by an external auditor of the company's financial information. External auditors who are in charge of the audit program are required to behave independently and are prohibited from taking sides with one of the parties, namely the principal or agent. The information contained in the external auditor's audit report will be used by the principal in determining the basis for decisions of short-term and long-term interests on ownership of the company.

\section{Stakeholders Theory}

Freeman (2010) states that stakeholder theory is a theory that shows several parties that are the target of corporate responsibility in relation to their activities. The mentioned party is a group or individual that can impact or be affected by the results of the company's objectives. Stakeholders theory explains that in addition to how company management discloses information, company management is also responsible for providing performance values within a predetermined period to investors as part of the stakeholders. There is also a conflict of interest that occurs between company management and investors as owners of the company, one of which is the failure to fulfill investors' expectations of management whose task is to optimize the company's performance. The company management has 
personal interests that conflict with the interests of investors as company stakeholders. In dealing with conflicts that occur in the company, it is necessary to have an independent party called an external auditor or public accountant who functions as a third party to overcome and harmonize conflicts that occur between the two parties. Stakeholders theory also deals with audit quality. External auditors are required to maintain audit quality to maintain objectivity, reliability, and independence in disclosing company information to realize the quality of audit reports as the responsibility of investors. Thus, the audit report also contains an external auditor's opinion that can assist stakeholders in understanding the quality of the company's value.

\section{Legitimacy Theory}

Gray et al. (1995) state that the legitimacy theory is a theory that is the rationale for explaining that an organization or company will continue to exist if society realizes that the organization operates with a value system that is by the community's value system. Legitimacy theory is a theory based on achieving status when a firm's value system is in line with a larger social value system. In this case, the larger social system is the system owned by stakeholders, in which stakeholders are shareholders or investors and the community. Legitimacy theory positions the independent auditor as a party to the organization, namely the Public Accounting Firm with investors and the public as stakeholders. The norms attached to stakeholders (investors and society) can be convinced by the existence of a professional code of ethics and professional standards of public accountants. As the code of ethics and audit standards are the legitimate responsibility of the auditor's professionalism in implementing social norms and values, as well as the quality expected by shareholders and society. This is because if an ethical audit process and quality are realized according to the professional standards of the public accountant, it will be able to produce harmony between the company's value system and the social system of stakeholders (investors and society) and represent the fulfillment of community norms thus increasing credibility, reputation, public trust, and the realization of company legitimacy, in this case, an independent auditor, namely a public accounting firm.

Based on the literature review that has been carried out, a research model can be built as shown in Figure 1.

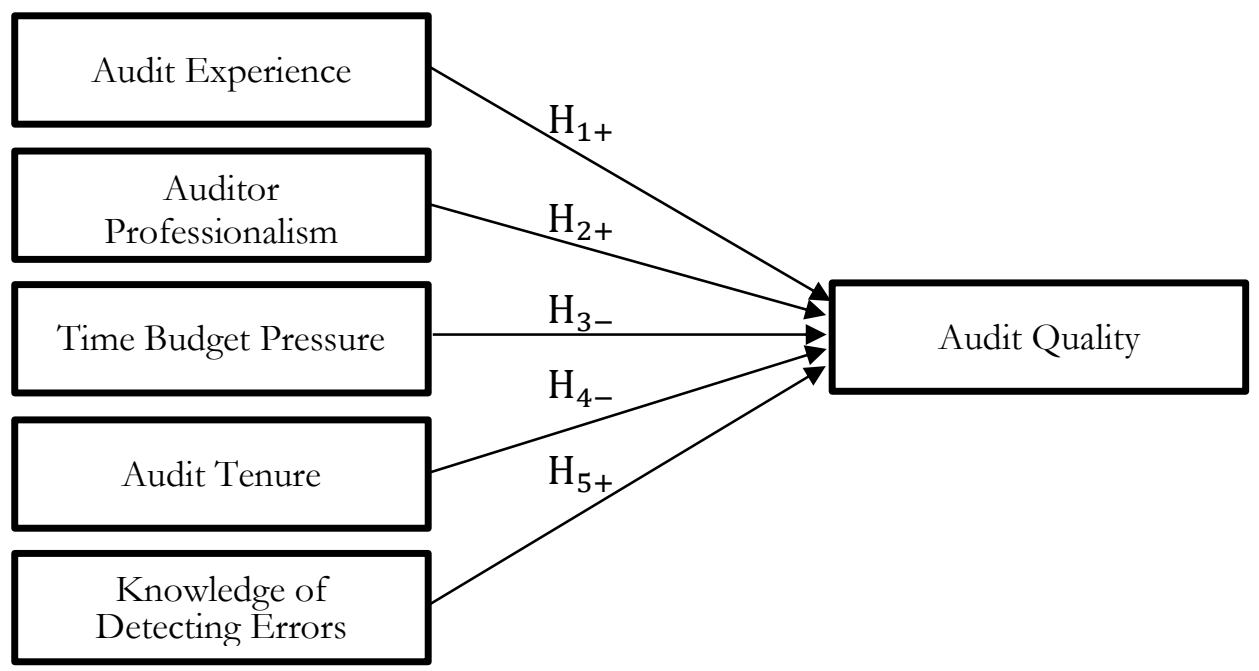

Figure 1. Research Model

\section{Relationship Between Audit Experience and Audit Quality}

Stakeholder theory links experience to audit quality. External auditors are required to have adequate audit experience as a basis for maintaining audit quality in the form of objectivity, reliability, 
independence in disclosing information on the company's financial statements in the audit report to investors. A quality audit report will be considered by investors to see the company's financial position regarding its investment activities.

Experienced external auditors can successfully minimize errors or prevent accidental audit failures. This can be used as a recommendation that the longer work experience an external auditor has, the more it will affect the quality of the examination results (Masrizal, 2010). Mulyadi (2013)states that auditor experience has a significant and positive effect on audit quality. The results of research on the experience of auditors conducted by Slamet (2012) Nirmala et al. (2013), Wulandari et al. (2014) also found that auditor experience has a significant and positive effect on audit quality.

Audit experience is a key requirement as a professional external auditor. External auditors who have sufficient experience will have competence in dealing with the conditions in the client company area while on duty. Experienced external auditors can successfully minimize errors or prevent accidental audit failures.

$\mathbf{H}_{\mathbf{1}}$ : Auditor experience has positive effect on audit quality

\section{Relationship between Audit Professionalism and Audit Quality}

Stakeholder theory is closely related to the professionalism of external auditors. This theory is the basis for encouraging the public accounting profession to always guarantee the professionalism of external auditors in carrying out audit task procedures. Legitimacy theory also influences auditor professionalism. Besides every external auditor must comply with the professional standards of public accountants as the responsibility of the audit profession in producing good quality audits for the benefit of shareholders, external auditors must comply with and implement the basic principles of a professional code of ethics.

Mulyadi (2013) states that auditor professionalism has a significant positive effect on audit quality. Implicitly, the professionalism of auditors is an absolute requirement in producing good and correct audit quality.

Every professional external auditor has the competence and knowledge that is expected to minimize audit errors and find material misstatements in the client company's financial statements so that the audit report is objective. Therefore, the more professional an external auditor is, the better the resulting audit quality.

$\mathbf{H}_{2}$ : Auditor professionalism has positive effect on audit quality

\section{Relationship between Time Budget Pressure and Audit Quality}

In stakeholder theory and legitimacy theory, time budget pressure is related to auditor professionalism as a challenge in carrying out audit procedures according to professional standards of public accountants and the basic principles of the professional code of ethics. Auditors are responsible for the interests of stakeholders, particularly investors and public trust, resulting in the independent, objective, and relevant audit quality. Ningsih and Yaniartha (2013) state that time budget pressure has a significant negative effect on audit quality. Furthermore, Nirmala et al. (2013) also found that time budget pressure has a significant negative effect on audit quality.

Availability of time is crucial in gathering audit evidence and finding misstatements in client's financial statements for any external auditor. The higher the time pressure given, the higher the stress experienced so that the auditor is forced to reduce audit procedures. If the audit procedures are not by what was planned before, it will result in poor audit quality.

$\mathbf{H}_{3}$ : The auditor's time budget pressure has negative effect on audit quality

\section{Relationship between Audit Tenure and Audit Quality}

Stakeholder theory states that every external auditor who carries out his duties must be based on auditing standards. Furthermore, the legitimacy theory also states that the public accounting 
profession and client companies are obliged to create harmony between the values inherent in their activities based on the basic principles of the professional code of ethics. With compliance with the professional standards of public accountants and the basic principles of this professional code of ethics, every external auditor is required to be professional in facing obstacles when carrying out audit duties.

Kurniasih and Rohman (2014)state that audit tenure has a significant negative effect on audit quality. Research by Panjaitan and Chariri (2014) also found that audit tenure has a significant negative effect on audit quality.

Each external auditor is required to be professional based on the experience gained to understand how to behave towards client companies to comply with the professional standards of public accountants, the basic principles of the code of ethics, and applicable laws in creating quality audit results.

$\mathbf{H}_{\mathbf{4}}$ : Audit tenure has negative effect on audit quality

\section{Relationship between Knowledge of Detecting Errors and Audit Quality}

Legitimacy theory requires that the work of the audit profession be in line with the social values of shareholders and society. This is the demand for every professional external auditor to have a variety of knowledge, one of which is the knowledge of detecting errors to prevent audit failure by the guidelines against the professional standards of public accountants and the basic principles of the professional code of ethics.

Hilman et al. (2015) show that knowledge of detecting audits affects audit quality. These findings imply that the knowledge of detecting errors affects audit quality.

Knowledge of detecting errors is good because having this knowledge can make it easier for external auditors to disclose misstatements through accurate materiality considerations of the client company's financial statements so that the audit report becomes quality because it fulfills the element of objectivity. This shows the influence of the knowledge of detecting errors on audit quality.

$\mathbf{H}_{\mathbf{5}}$ : Knowledge of detecting errors has positive effect on audit quality

\section{Research Method}

This study uses a quantitative approach. Quantitative research is a scientific method whose data is in the form of numbers or numbers that can be processed and analyzed using mathematical or statistical calculations (Sekaran \& Bougie, 2016). This research method is used based on a specific population or sample with the sampling generally random.

Data collection uses research instruments and data analysis is quantitative or statistical to test predetermined hypotheses. The variables of this research are experience, auditor professionalism, time budget pressure, audit tenure, and knowledge of detecting errors in audit quality. Data was collected by distributing a questionnaire containing a list of questions filled out by the respondents. Collecting data through distributing questionnaires directly to independent auditors of public accounting firms in Jakarta which are registered in the Public Accounting Firm Information System (SIKAP) issued by BPK RI. Respondents of this study were auditors at a public accounting firm in Jakarta. The research sample is determined based on the Slovin formula so that from a population of 846 auditors with a critical value level of $10 \%$, the total sample size is 89 .

\section{Operational Definition of Research Variables}

\section{Audit quality}

Audit quality indicators consist of detection of misstatements, compliance with SPAP, compliance with SOPs, audit risk, prudential principles, control by supervisors, and attention given by managers or partners. Measured by using 10 statement items with a 5-point Likert scale. 


\section{Auditor experience}

Auditor's experience indicator consists of the length of work as an auditor and the number of audit tasks. Measured by using 7 statement items with a 5-point Likert scale.

\section{Auditor professionalism}

Indicators of auditor professionalism consist of devotion to the profession, social obligations, independence, professional beliefs, and relationships with colleagues. Measured by using 15 statement items with a 5-point Likert scale.

\section{Time budget pressure}

Fleming (1980) states that the time budget pressure indicator consists of planning and time effectiveness. Measured by using 5 statement items with a 5-point Likert scale.

\section{Audit tenure}

Audit tenure indicators consist of the length of time working as an auditor, the length of time the auditor deals with clients, and the length of time he audits the client. Measured by using 7 statement items with a 5-point Likert scale.

\section{Knowledge of detecting errors}

Knowledge indicator for detecting errors consists of the many experiences of the auditor in auditing a financial report, having served as chairman of the audit team, a professional education background according to the profession, and having attended training, seminars, or workshops 2 or more times. Measured by using 8 statement items with a 5-point Likert scale.

\section{Data analysis technique}

The data analysis technique used includes analysis of the validity and reliability tests. The classical assumption tests carried out included data normality, multicollinearity and heteroscedasticity tests.

Furthermore, the coefficient of determination $\left(\mathrm{R}^{2}\right)$ test was also carried out, and the partial test using the $\mathrm{t}$-test, and the $\mathrm{f}$-test to determine the simultaneous effect of the independent variables on the dependent variable.

\section{Result and Discussion}

\section{Demographics of Respondents}

The object of this research is the auditor of a public accounting firm in Jakarta. The data collection technique in this study used a survey method, the distribution of this questionnaire took place from March 8 to April 32018 by distributing 91 questionnaires. The use of the questionnaire consisted of 89 questionnaires that were returned and 2 questionnaires that were not returned.

Table 1. Questionnaire Distribution

\begin{tabular}{lc}
\hline \multicolumn{1}{c}{ Explanation } & Total \\
\hline Distributed questionnaires & 91 \\
Questionnaire that cannot be used & $(2)$ \\
Questionnaire that can be used & 89 \\
\hline
\end{tabular}

The demographics of the questionnaire consisted of 50 junior auditor respondents, 33 senior auditor respondents, and 6 manager respondents, and the total male respondent as many as 49 respondents and 40 female respondents. 
Table 2. Respondent Characteristics

\begin{tabular}{llcc}
\hline & Demographics & Total & Percentage \\
\hline Gender: & Male & 49 & 55 \\
& Female & 40 & 45 \\
\hline Position: & Junior auditor & 50 & 56 \\
& Senior auditor & 33 & 37 \\
& Manager & 6 & 7 \\
\hline
\end{tabular}

\section{Validity and Reliability Test Results}

The validity test used in this study is to calculate the correlation using Pearson Correlation. If rcount $>$ r-table, then the item is declared valid. In this study, the validity test was conducted using a significance value of 0.05 and obtained r-table of 0.28 .

The reliability test was conducted to determine whether the research instrument, in this case, the questionnaire, could be used more than once to the same respondent, which would produce consistent data. The reliability test also serves to measure whether the respondent's answer in the form of a questionnaire statement is an indicator of the variable. The indicator for the reliability test is Cronbach Alpha, if Cronbach Alpha> 0.60 indicates the instrument used is reliable.

\section{Descriptive Statistic}

Table 3. Descriptive Statistics Results

\begin{tabular}{lrrrrr}
\hline & N & \multicolumn{1}{l}{ Min } & Max & Mean & Std. Dev. \\
\hline Audit quality & 89 & 3.60 & 5 & 4.16 & 0.33 \\
Audit experience & 89 & 2.86 & 5 & 4.20 & 0.39 \\
Audit professionalism & 89 & 3.40 & 5 & 4.24 & 0.32 \\
Time budget pressure & 89 & 1.60 & 5 & 3.57 & 0.71 \\
Audit tenure & 89 & 2.43 & 5 & 3.70 & 0.49 \\
Knowledge of detecting errors & 89 & 2.63 & 5 & 4.04 & 0.36 \\
\hline
\end{tabular}

It is known that the minimum value for the audit quality variable data $(Y)$ is 3.60, while the maximum value is 5 so that the average value of respondents' answers to statements is 4.16 with a standard deviation of 0.33 . The standard deviation value smaller than the average (mean) can represent the overall data well. It can be seen from the average value (mean) shows a value of 4.16 which means agreeing. This shows that the quality of audits by independent auditors at public accounting firms in Jakarta is good.

The auditor's experience as a variable $\mathrm{X}_{1}$ has a minimum value of 2.86 , while a maximum value of 5 so that the average value of the answers to respondents' statements is 4.20 with a standard deviation of 0.39 . The standard deviation value smaller than the average (mean) can represent the overall data well. It can be seen from the average value (mean) shows 4.20 which means agreeing. This shows that the experience of independent auditors at public accounting firms in Jakarta is good.

Auditor professionalism as a variable $\mathrm{X}_{2}$ has a minimum value of 3.40 , while a maximum value of 5 so that the average value of respondents' answers is 4.24 with a standard deviation of 0.32 . The standard deviation value smaller than the average (mean) can represent the overall data well. It can be seen from the average value (mean) shows 4.24 which means agreeing and good. This shows that the professionalism of independent auditors at public accounting firms in Jakarta is good.

Time budget pressure as the $\mathrm{X}_{3}$ variable has a minimum value of 1.60 , while the maximum value is 5 so that the average value of respondents' answers is 3.57 with a standard deviation of 0.71 . The standard deviation value smaller than the average (mean) can represent the overall data 
well. It can be seen from the mean value of 3.57 , this indicates that the time pressure or time budget at public accounting firms in Jakarta is quite tight.

Audit tenure as the $\mathrm{X}_{4}$ variable has a minimum value of 2.43 , while the maximum value is 5 so that the average value of the respondents' answers is 3.70 with a standard deviation of 0.49 . The standard deviation value smaller than the average (mean) can represent the overall data well. It can be seen from the average value (mean) of 3.70, this indicates that the audit engagement period or tenure of public accounting firms in Jakarta is quite long.

Knowledge of detecting errors as a variable $\mathrm{X}_{5}$ has a minimum value of 2.63 , while a maximum value of 5 so that the average value of respondents' answers is 4.04 with a standard deviation of 0.36 . The standard deviation value smaller than the average (mean) can represent the overall data well. It can be seen from the mean value of 4.04, this indicates that the independent auditors agree with the knowledge that detecting errors has a significant effect on audit quality and is fairly good.

\section{Classical Assumption Test}

The data normality test using the Kolmogorov-Smirnov test resulted in a Kolmogorov-Smirnov value of 1.346 with a significance level of 0.053 . Data requirements are normally distributed if the significance level is greater than 0.05 , but the data is not normally distributed if the significance level is below 0.05 . Thus it can be concluded that the data in this study were normally distributed.

If the tolerance value on the test result is greater than 0.10 and the VIF value is less than 10.00 , it is ensured that there are no symptoms of multicollinearity, whereas if the tolerance value is less than 0.10 and the VIF value is greater than 10.00, it is confirmed that there are multicollinearity symptoms. Multicollinearity test results present in Table 4. It can be concluded that there is no multicollinearity in the regression model.

Table 4. Multicollinearity test results

\begin{tabular}{cccc}
\hline Variable & Tolerance & VIF & Keterangan \\
\hline $\mathbf{X}_{\mathbf{1}}$ & 0.502 & 1.990 & multicollinearity does not occur \\
$\mathbf{X}_{\mathbf{2}}$ & 0.479 & 2.086 & multicollinearity does not occur \\
$\mathbf{X}_{\mathbf{3}}$ & 0.523 & 1.912 & multicollinearity does not occur \\
$\mathbf{X}_{\mathbf{4}}$ & 0.371 & 2.693 & multicollinearity does not occur \\
$\mathbf{X}_{\mathbf{5}}$ & 0.586 & 1.706 & multicollinearity does not occur \\
\hline
\end{tabular}

Table 5 shows the results of the Glejser Test to test whether there are symptoms of heteroscedasticity or not in the regression model. It appears that each variable has a significance value of more than or above 0.05 . This shows that there is no heteroscedasticity in this research variable.

Table 5. Heteroskedasticity test results

\begin{tabular}{cccc}
\hline Variable & Sig. & $\alpha$ & Keterangan \\
\hline $\mathbf{X}_{\mathbf{1}}$ & 0.524 & 0,05 & heteroscedasticity does not occur \\
$\mathbf{X}_{\mathbf{2}}$ & 0.828 & 0,05 & heteroscedasticity does not occur \\
$\mathbf{X}_{\mathbf{3}}$ & 0.289 & 0,05 & heteroscedasticity does not occur \\
$\mathbf{X}_{\mathbf{4}}$ & 0.320 & 0,05 & heteroscedasticity does not occur \\
$\mathbf{X}_{\mathbf{5}}$ & 0.393 & 0,05 & heteroscedasticity does not occur \\
\hline
\end{tabular}

\section{Multiple Linear Regression Analysis Results}

The results showed that the research data were normally distributed, free from multicollinearity, and certainly free from heteroscedasticity. Furthermore, multiple linear regression analysis tests 
were carried out using the SPSS 20 version for Windows 8 software. The test results are shown in Table 6.

Table 6. Multiple Linear Regression Analysis Results

\begin{tabular}{lcccc}
\hline \multicolumn{1}{c}{ Variable } & Regression Coefficient & t-count & Notes & Sig. \\
\hline Constanta & 10.950 & 2.961 & $\geq 1.988$ & 0.004 \\
Auditor Experience $\left(\mathrm{X}_{1}\right)$ & 0.530 & 4.040 & $\geq 1.988$ & 0.000 \\
Audit professionalism $\left(\mathrm{X}_{2}\right)$ & 0.106 & 1.401 & $<1.988$ & 0.165 \\
Time Budget Pressure $\left(\mathrm{X}_{3}\right)$ & 0.000 & 0.004 & $<1.988$ & 0.997 \\
Audit Tenure $\left(\mathrm{X}_{4}\right)$ & -0.009 & -0.073 & $<1.988$ & 0.942 \\
Knowledge of detecting errors $\left(\mathrm{X}_{5}\right)$ & 0.265 & 2.308 & $\geq 1.988$ & 0.024 \\
\hline
\end{tabular}

Based on data of Table 6 , then can be explained that:

a. The audit quality constant $(\mathrm{Y})$ is 10.950 , which means that if the variable auditor experience $\left(\mathrm{X}_{1}\right)$, auditor professionalism $\left(\mathrm{X}_{2}\right)$, time budget pressure $\left(\mathrm{X}_{3}\right)$, audit tenure $\left(\mathrm{X}_{4}\right)$, and knowledge of detecting errors $\left(\mathrm{X}_{5}\right)$ is 0 , then the audit quality $(\mathrm{Y})$ of 10.950 .

b. The coefficient of the auditor experience variable $\left(\mathrm{X}_{1}\right)$, which is 0.530 , has a positive regression coefficient. This indicates that the experience of auditors has a positive effect on audit quality, or functionally it can be stated that if the experience of auditors increases, it can improve audit quality.

c. The coefficient of the auditor professionalism variable $\left(\mathrm{X}_{2}\right)$, namely 0.106 , has a positive regression coefficient. This shows that auditor professionalism has a positive effect on audit quality, or functionally it can be stated that if the professionalism of auditors increases, it can improve audit quality.

d. The time budget pressure variable coefficient $\left(\mathrm{X}_{3}\right)$, which is 0.000 , has a positive regression coefficient sign. This shows that time budget pressure has a positive effect on audit quality, or functionally it can be stated that if time budget pressure increases, it can improve audit quality.

e. The coefficient of the audit tenure variable $\left(\mathrm{X}_{4}\right)$ which is -0.009 has a negative regression coefficient sign. This indicates that audit tenure has a negative effect on audit quality, or functionally it can be stated that if audit tenure increases, it can reduce audit quality.

f. The coefficient of the knowledge variable to detect errors $\left(\mathrm{X}_{5}\right)$, namely 0.265 , has a positive regression coefficient. This shows that the knowledge of detecting errors has a positive effect on audit quality, or functionally it can be stated that if the knowledge of detecting errors increases, it can improve audit quality.

\section{F Test Result}

The results of the $\mathrm{F}$ test on the research model show a significance value less than $0.05(0.000$ $<0.05)$ as a requirement for the $\mathrm{F}$ test. Thus, it shows that the independent variables are auditor experience $\left(\mathrm{X}_{1}\right)$, auditor professionalism $\left(\mathrm{X}_{2}\right)$, time budget pressure $\left(\mathrm{X}_{3}\right)$, audit tenure $\left(\mathrm{X}_{4}\right)$, and knowledge of detecting errors $\left(\mathrm{X}_{5}\right)$ simultaneously influence the dependent variable, namely audit quality (Y).

\section{Coefficient of Determination $\left(\mathbf{R}^{2}\right)$}

The coefficient of determination resulting from the research data processing shows several 0.500 . This explains that the contribution of the influence of the independent variables, namely auditor experience $\left(\mathrm{X}_{1}\right)$, auditor professionalism $\left(\mathrm{X}_{2}\right)$, time budget pressure $\left(\mathrm{X}_{3}\right)$, audit tenure $\left(\mathrm{X}_{4}\right)$, and knowledge of detecting errors $\left(\mathrm{X}_{5}\right)$ on the dependent variable, namely audit quality $(\mathrm{Y})$ equal to $50 \%$ of $100 \%$ while $50 \%$ is influenced by other variables outside this regression model. 


\section{T-test Results}

Tabel 5. T-test results

\begin{tabular}{lrrrrr}
\hline \multicolumn{1}{c}{ Model } & \multicolumn{2}{c}{$\begin{array}{c}\text { Coefficient Value } \\
\text { (unstandardized) }\end{array}$} & $\begin{array}{l}\text { Std. Value } \\
\text { (standardized) }\end{array}$ & $\mathrm{t}$ & Sig. \\
\cline { 2 - 6 } & \multicolumn{1}{c}{$\mathrm{B}$} & Std. Error & & & \\
Constant & 10.950 & 3.698 & & 2.961 & 0.004 \\
Audit experience & 0.530 & 0.131 & 0.442 & 4.040 & 0.000 \\
Audit professionalism & 0.106 & 0.075 & 0.157 & 1.401 & 0.165 \\
Time Budget Pressure & 0.000 & 0.099 & 0.000 & 0.004 & 0.997 \\
Audit Tenure & -0.009 & 0.122 & -0.009 & -0.073 & 0.942 \\
Knowledge of detecting errors & 0.265 & 0.115 & 0.234 & 2.308 & 0.024 \\
\hline
\end{tabular}

\section{Results and Discussion}

Based on Table 7, it is obtained the t-value of the auditor experience variable of 4.040 and a significance value of 0.000 . This shows that the value of t-count $4.040>\mathrm{t}$-table 1.988 and a significant value of $0.000<0.05$. Therefore, auditor experience has a significant effect on audit quality so that the first hypothesis $\left(\mathrm{H}_{1}\right)$ is accepted. The results of this study are in line with agency theory, stakeholder theory, and legitimacy theory. Agency theory shows the need for an independent party, namely external auditors in revealing information asymmetry between company owners (shareholders) and company management (agents). In addition, stakeholder theory shows that company activities are required to carry positive values as a responsibility to the interests of stakeholders for their investment.

Based on Table 7, it is obtained the t-value of the auditor professionalism variable of 1.401 and a significance value of 0.165 . This shows that the value of $\mathrm{t}$-count $1.401<\mathrm{t}$-table 1.988 and a significant value of $0.165>0.05$. Therefore, auditor professionalism has no effect on audit quality so that the second hypothesis $\left(\mathrm{H}_{2}\right)$ is rejected. The results of this study are by the stakeholder theory which shows that the professionalism of auditors has an effect on the good quality of the audit but not significantly. That to create quality audit report results, a professional external auditor is needed.

Based on Table 7, the t-value of the time budget pressure variable is 0.004 and the significance value is 0.997 . This shows that the $\mathrm{t}$-count value is $0.004<\mathrm{t}$-table 1.988 and the significant value is $0.997>0.05$. Therefore, time budget pressure has no effect on audit quality so that the third hypothesis $\left(\mathrm{H}_{3}\right)$ is rejected. The results of this study indicate that every external auditor who becomes a respondent can maintain his focus in facing the audit task in accordance with the strictness of the time budget. This is done as a manifestation of the consistency and commitment of the accounting profession for each auditor so that this is in accordance with the values of stakeholder theory and the theory of legitimacy that underlies the role of external auditors in their duties.

Based on Table 7, the $t$-value of the audit tenure variable is -0.073 and a significance value of 0.942 . This shows that the $\mathrm{t}$-count value is $-0.073<\mathrm{t}$-table 1.98 and the significant value is $0.942>$ 0.05. Therefore, audit tenure has no effect on audit quality so that the fourth hypothesis $\left(\mathrm{H}_{4}\right)$ is rejected. The results of this study indicate that the length of the audit engagement period is not always a reference in assessing the audit quality of each external auditor. However, this study implies that stakeholder theory and legitimacy theory are demands of external auditors to be professional in facing various obstacles in carrying out their audit duties, one of which is the relationship between the audit tenure and the company that is the client.

Based on Table 7 , it is obtained the t-value of the knowledge variable to detect errors of 2.308 and a significance value of 0.024 . This shows that the value of $t$-count $2.308>t$-table 1.988 and a significant value of $0.024<0.05$. Therefore, knowledge of detecting errors has a significant effect on audit quality so that the fifth hypothesis $\left(\mathrm{H}_{5}\right)$ is accepted. The results of this study are 
consistent with agency theory and stakeholder theory. Agency theory shows the need for an independent party, namely external auditors in revealing information asymmetry between company owners (shareholders) and company management (agents). Furthermore, stakeholder theory shows that company activities are required to bring positive values as a responsibility to the interests of stakeholders.

\section{Conclusion}

Auditor experience has a positive and significant effect on audit quality at a public accounting firm in Jakarta. This shows that the higher the auditor's experience, the higher the quality of the resulting audit. Auditor professionalism has no significant effect on audit quality at public accounting firms in Jakarta. This shows that the higher the professionalism of the auditors, it does not guarantee a significant effect on the resulting audit quality. Time budget pressure has no significant effect on audit quality in public accounting firms in Jakarta. This shows that the higher the pressure on the audit time budget, the more it will not affect the quality of the audit. Audit tenure has a negative value and does not have a significant effect on audit quality. This shows that the longer the tenure of the public accounting firm to the client company, it will not significantly affect the quality of the resulting audit. Knowledge of detecting errors has a significant positive effect on audit quality at public accounting firms in Jakarta. This shows that the more adequate the knowledge to detect errors, the better the resulting audit quality.

Based on the results of this study, it can be shown whether or not the independent variables are affected, namely experience, auditor professionalism, time budget pressure, audit tenure, and knowledge of detecting errors on the dependent variable, namely audit quality. This research can be a concept development and analytical resource if further research wants to include the variables that have been determined in this study. This research is expected to be a driving force for further researchers to find other variables as a means of variation in research to gain valid new knowledge and information regarding audit quality factors.

The results of this study can be useful for public accounting firms to pay more attention and encourage each external auditor to improve work experience through the frequency of audit work, professional education with the help of the active role of public accounting firms and public accounting professional institutions so that each external auditor is able to maximize the audit results report. Quality is related to auditing standards to maintain the legitimacy of the public accounting profession in the form of values and norms for shareholders and the public. Experienced auditors are expected to be the basis for their actions to create efficient and effective audit procedures when performing audit tasks.

This research pays special attention to that lies in the audit engagement period or audit tenure. In general, audit tenure can interfere with the independence of auditors if it is considered long-term so that the quality of audit results is poor. Therefore, the government can review the policies that have been made regarding the period of the entity's engagement with the public accounting firm.

\section{References}

Arisinta, O. (2013). Pengaruh kompetensi, independensi, time budget pressure, dan audit fee terhadap kualitas audit pada kantor akuntan publik di Surabaya. Jurnal Ekonomi Dan Bisnis, 23(3), 266-278.

Behn, B. K., Choi, J.-H., \& Kang, T. (2008). Audit quality and properties of analyst earnings forecasts. The Accounting Review, 83(2), 327-349.

Broberg, P., Tagesson, T., Argento, D., Gyllengahm, N., \& Mårtensson, O. (2017). Explaining the influence of time budget pressure on audit quality in Sweden. Journal of Management \& 
Governance, 21(2), 331-350.

Davis, L. R., Soo, B., \& Trompeter, G. (2002). Auditor Tenure, Auditor Independence and Earnings Managemen.

Fleming, M. K. (1980). Budgeting practices in large CPA firms. Journal of Accountancy, 149(5), 5562.

Freeman, R. E. (2010). Strategic Management: A Stakeholder Approach. Cambridge University Press.

Futri, P. S., \& Juliarsa, G. (2014). pengaruh independensi, profesionalisme, tingkat pendidikan, etika profesi, pengalaman, dan kepuasan kerja auditor terhadap kualitas audit pada kantor akuntan publik di Bali. E-Jurnal Akuntansi Universitas Udayana, 7(2), 41-58.

Gray, R., Kouhy, R., \& Lavers, S. (1995). Corporate social and environmental reporting: A review of the literature and A longitudinal study of UK disclosure. Accounting, Auditing \& Accountability Journal, 8(2), 47-77.

Hilman, A. F., Rasuli, M., \& Anisma, Y. (2015). Pengaruh Pengetahuan mendeteksi kekeliruan dan etika profesi terhadap kualitas audit dengan pertimbangan tingkat materialitas sebagai variabel intervening (studi empiris pada kantor akuntan publik se Sumatera). Jurnal Akuntansi Fakultas Ekonomi Dan Bisnis Universitas Riau, 2(2), 1-15.

Jensen, C., \& Meckling, H. (1976). Theory of the Firm : Managerial behavior, agency costs and ownership structure. 3, 305-360.

Kurniasih, M., \& Rohman, A. (2014). Pengaruh fee audit, audit tenure, dan rotasi audit terhadap kualitas audit. Diponegoro Journal of Accounting, 3(3), 1-10.

Masrizal. (2010). Pengaruh pengalaman dan pengetahuan audit terhadap pendeteksian temuan kerugian daerah (studi pada auditor inspektorat Aceh). Jurnal Telaah Dan Riset Akuntansi, 3(2), 173-194.

Moroney, R., \& Carey, P. J. (2011). Industry versus task-based experience and auditor performance. Auditing: A Journal of Practice \& Theory, 30(2), 1-19.

Mulyadi. (2013). Pengaruh pengalaman kerja, kompetensi, independensi, akuntabilitas, profesionalisme dan kompleksitas tugas auditor terhadap kualitas audit (studi empiris pada KAP Surakarta dan Jogjakarta). Jurnal Akuntansi STIE Adi Unggul Bhirawa Surakarta, 1(2), 74-89.

Nasser, A. T. A., Wahid, E. A., Nazri, S. N. F. S. M., \& Hudaib, M. (2006). Auditor-client relationship: the case of audit tenure and auditor switching in Malaysia. Managerial Auditing Journal, 21(7), 724-737.

Ningsih, A. A. P. R. C., \& Yaniartha, P. D. (2013). A.A Putu Ratih Cahaya Ningsih. E-Jurnal Akuntansi Universitas Udayana, 4(1), 92-109.

Nirmala, A., Putri, R., \& Cahyonowati, N. (2013). Pengaruh independensi, pengalaman, due professional care, akuntabilitas, kompleksitas audit, dan time budget pressure terhadap kualitas audit (studi empiris pada auditor KAP di Jawa Tengah dan DIY). Diponegoro Journal of Accounting, 2(3), 786-798.

Panjaitan, C. M., \& Chariri, A. (2014). Pengaruh tenure, ukuran KAP, dan spesialisasi auditor terhadap kualitas audit. Diponegoro Journal of Accounting, 3(3), 1-12.

Probohudono, A. N., Sugiharto, B., \& Arifah, S. (2019). The Influence of corporate governance, audit quality, and ownership, on financial instrument disclosure in Indonesia. Journal of Contemporary Accounting, 1(3), 173-187. https://doi.org/10.20885/jca.vol1.iss3.art5 
Sekaran, U., \& Bougie, R. (2016). Research Method for Business Textbook: A Skill Building Approach. Wiley.

Slamet, I. S. (2012). Pengaruh pengalaman kerja, independensi, dan kompetensi auditor terhadap kualitas audit oleh akuntan publik di Surabaya. Berkala Ilmiah Mahasiswa Akuntansi, 1(1), 102-106.

Wardayati, S. M., Miqdad, M., Efendi, H. I., \& Arisandy, F. N. (2019). Performance improvement through internal control, experience and individual rank. Journal of Contemporary Accounting, 1(2), 107-119. https://doi.org/10.20885/jca.vol1.iss2.art4

WE Online. (2017, September 16). Refleksi Untuk Profesi Auditor Atas Kasus KPMG dan PwC. Warta Ekonomi. https://www.wartaekonomi.co.id/read154644/refleksi-untuk-profesiauditor-atas-kasus-kpmg-dan-pwc

Wulandari, N., Rasuli, \& Diyanto, V. (2014). Pengaruh pengalaman, pengetahuan, audit tenure, dan peer review terhadap kualitas audit (studi empiris pada kantor akuntan publik di Pekanbaru, Batam, Padang dan Medan). Jurnal Jurusan Akuntansi Fakultas Ekonomi Universitas Riau, 1(2), 1-16.

Zam, D. R. P., \& Rahayu, S. (2015). Pengaruh tekanan anggaran waktu (time budget pressure), fee audit, dan independensi auditor terhadap kualitas audit (studi kasus pada kantor akuntan publik di wilayah Bandung). Jurnal Akuntansi Fakultas Ekonomi Dan Bisnis Universitas Telkom, 2(2), 1800-1807. 